\title{
THE LEARNING STRATEGIES USED BY EFL STUDENTS IN LEARNING ENGLISH
}

\author{
Dinda Hartina Mega Sartika, Asih Santihastuti, Eka Wahjuningsih \\ University of Jember, Indonesia \\ (dindamega6@gmail.com)
}

Received: $12^{\text {th }}$ April 2019; Revised: $28^{\text {th }}$ May 2019; Accepted: $28^{\text {th }}$ June 2019

\begin{abstract}
This research was aimed to focus on the most frequently used strategy by the successful and unsuccessful senior high school students and describe the difference of strategy used by them. This was a survey design with a questionnaire as the instrument. The participants were 40 students consisting of 20 successful students and 20 unsuccessful students of tenth grade in SMAN 2 Jember. The writer distributed SILL questionnaires to observe their Language Learning Strategy (LLS) based on Oxford (1990), which covers six categorizes of strategies namely cognitive, metacognitive, memory-related, compensatory, affective, and social. The statistical analysis showed that metacognitive became the most frequently learning strategy used by successful students in scale of high use, while the unsuccessful students were medium users of cognitive strategy. It also indicated successful learners employed all six categorizes of strategies in a highly frequencies than the unsuccessful ones. This makes the assumption that successful students have the ability to plan clear goals, control, review, and evaluate their learning rather than unsuccessful students who focus more on the way they think, memorize, summarize, and repeat the learning.
\end{abstract}

Key Words: Language Learning Strategy; EFL learners; SILL questionnaire

\section{ABSTRAK}

Penelitian ini bertujuan untuk fokus pada strategi yang paling sering digunakan oleh siswa SMA yang sukses dan kurang sukses serta menggambarkan perbedaan strategi yang digunakan oleh mereka. Penelitian ini merupakan penelitian survey dengan instrument berupa kuesioner, sedangkan tanggapan siswa dalam memilih strategi dibahas secara deskriptif. Partisipan adalah 40 siswa yang terdiri dari 20 siswa yang sukses dan 20 siswa yang tidak sukses dari kelas sepuluh di SMAN 2 Jember. Penulis membagikan kuesioner SILL untuk mengamati Language Learning Strategy (LLS) atau strategi pembelajaran bahasa mereka berdasarkan teori Oxford (1990, yang dikategorikan menjadi enam macam strategi, yaitu kognitif, metakognitif, memori, kompensatori, afektif, dan sosial. Menurut hasil statistic metacognitive menjadi strategi pembelajaran yang paling sering digunakan oleh siswa yang sukses dalam skala tinggi, sedangkan siswa yang kurang sukses adalah pengguna menengah dari strategi kognitif. Ini juga menunjukkan bahwa siswa yang sukses menggunakan keenam kategori strategi dalam frekuensi yang sangat tinggi daripada yang kurang sukses. Ini membuat asumsi bahwa siswa yang sukses memiliki kemampuan untuk merencanakan tujuan yang jelas, mengendalikan, meninjau, dan mengevaluasi pembelajaran mereka daripada siswa yang kurang sukses, yang lebih fokus pada cara mereka berpikir, menghafal, merangkum, dan mengulangi pembelajaran.

Kata Kunci: Strategi Pembelajaran Bahasa; peserta didik EFL; kuesioner SILL

How to Cite: Sartika, D. H. M., Santihastuti, A., Wahjuningsih, E. (2019). The Learning Strategies Used by EFL Students in Learning English. IJEE (Indonesian Journal of English Education), 6(1), 10-20. doi:10.15408/ijee.v6i1.12111

IJEE (Indonesian Journal of English Education), 6 (1), 2019, 10-20

P-ISSN: 2356-1777, E-ISSN: 2443-0390 | DOI: http://doi.org/10.15408/ijee.v6i1.12111

This is an open access article under CC-BY-SA license (https://creativecommons.org/licenses/by-sa/4.0/) 


\section{INTRODUCTION}

On the field of learning strategy, Language Learning Strategy (LLS) plays an important role in learning process. In language research recently, learning strategies are conscious, teachable, intentional, self-chosen, and self-regulated thoughts and actions for learning the target culture and language (Oxford, 2017). Earlier than that, more definition were added by O'Malley and Chamot, which (1993) described learning strategies as "the special thoughts or behaviors that individuals use to help them comprehend, learn, or retain new information". Simply it is found that LLS is what students think and act to accomplish a learning goal in learning process. They can select the activity based on their preference in order to make learning becomes more enjoyable. For example, some students practice English with friends at schools and some practice English with people who can speak English outside the classroom. Some students also practice English by reading English text and some by listening to music in English. Various strategies are performed by learners in order to improve their English and help them achieve their goal in learning. Moreover, applying learning strategies influence students in terms of their independency and where they learn how to manage their learning in such various ways. O'Malley \& Chamot (1990) stated that language learning strategies are applied by language learners as a means to acquire and to use information acquired, stored or recalled by the learners, and can also promote autonomy learning. This happened because language learning strategy indirectly guides the students to become active learners that can provide their own needs and choose their preference in learning the language. Briefly, we can say that, the more students are able to apply strategies, the more they become successful learners, because they know their goal and find any ways to achieve it. This makes an assumption that successful learners use more strategies than unsuccessful learners, due to their capability in applying strategies better as they know their needs in learning. Drawing to the attention, the results of Li (2009) in his study also was in line with the idea that successful learners are more in favor of using more learning strategies to learn rather than unsuccessful learners. He found in his study that successful learners are more aware in learning as they know how importance it is, that it also motivated them to become successful through applying more strategies often to get more benefits than usual. 
Earlier, it was also observed that successful learners are capable of using various learning strategy properly compared with the unsuccessful learners (Oxford, 1996). In brief, we can assume that there is a strong comparison of strategy learning used between the successful and unsuccessful learners. Therefore, it is interesting to know what strategies that successful and unsuccessful learners do in learning English so that it gives some information or the teacher, especially to help students learn better.

Oxford (1990) categorized Language Learning Strategies (LLS) into six aspects; cognitive, metacognitive, memory-related, compensatory, affective, and social, in which it represents both in direct and indirect toward learners' behavior and activities. Cognitive strategy enables the learner to produce new language materials in direct ways, for examples by doing reasoning, analysis, notetaking, summarizing, practicing structures and sounds formally. Metacognitive strategy is a strategy that is much more related to planning, arranging organizing, and evaluating the materials. Memory-related strategies help learners to learn and retrieve information in remembering through sound, word, images, acronym, rhyming, gestures, and combination from some of them.
Compensatory strategy is a strategy where students are guessing from the context they have in listening and reading. Affective strategies cover the activities of understanding learners' mood and anxiety level. Social strategies reveal students' interaction with others. These six categories are intentionally used and controlled by the learner themselves.

To identify this, Oxford has developed a model of questionnaire, which is popular as SILL (Strategy Inventory for Language Learning). Its function is to investigate the types of LLS by giving range for certain behaviors representing students in learning English. SILL has been widely used by lots of researchers as a part of empirical tool in the success of worldwide language learning, for examples, in Korea, the result reported that metacognitive and cognitive strategies were frequently mentioned as effective strategies represented by successful colleges learners in university level (Lee, J., \& Heinz, M. 2016), as well as another study that was conducted in Spain (Dmintreko, V. 2016), also found that adults learners tend to use metacognitive and cognitive strategies too. In Iranian, the investigation showed that successful learners, in which it categorized as a group of students with high grade of TOEFL and got mean score more than 
3.5 in SILL questionnaire, used wider range of metacognitive strategies while unsuccessful learners preferred to use surface level cognitive strategies (Gerami, H., \& Baighlou, S., 2011).

This present study focused on the most frequently used strategy by the successful and unsuccessful senior high school students and describe the difference of strategy used by them. In addition, the result of this study can hopefully provide a benefit that covers a facilitation to enhance teaching and learning quality by knowing the students' strategy choice as it can help them to become more active, creative, and autonomous. For the teachers, this study could give some insight on the facts that some students are having difficulty in their learning because they are unable to adjust their learning into different kinds of strategy variations. By knowing this, teachers could reflect on their teaching by creating and accustoming various approach and techniques during the teaching and learning process for the students to be familiar with any activity that represent the strategies that the students could employed by themselves later on.

\section{METHOD}

This present study was conducted by using survey design. The present study was conducted in a public senior high school SMAN 2 Jember. This school is included in the second place as the most preferable school in Jember Regency (As cited in RadarJember, 2018). Specifically, there were 40 students consisting of 20 successful students and 20 unsuccessful students. The criteria for categorization was students' grade point average in the odd semester, in which, according to the school rules, successful students are identified as those who had passed the score 86 in the odd semester, whereas unsuccessful students are identified as those whose score were less than 86 . The data collection method in this research was in the form of questionnaire. The research instrument used to collect the data was SILL (Strategy Inventory for Language Learning) version 7.0 (ESL/EFL) developed by Oxford (1990). The questionnaire was in the form of Likert/scoring data, and was translated into Bahasa Indonesia to avoid misinterpretation. The questionnaires were distributed to all selected participants in the school that had been put together into one classroom. The researcher accompanied the process of filling up the questionnaires, as well as was the guide for students who wanted to propose the questions related to the questionnaires. The data analysis resulted in a number of quantitative and qualitative findings which gave the 
researcher a better understanding of what they might have contributed in strategy language learning. All data was calculated by using Statistical Package for Social Sciences (SPSS) version 17.0 and revealed successful and unsuccessful specific strategies that they employed the most in EFL learning. In addition, the writer analyzed how well the strategies affected students by the scale they were categorized. there are three scales, according to Oxford (1990), that represent how frequently the students used the strategies by determining from the average of scores students choose in each item of question which is ranging from 1-5, which are;

a. Highly used (Mean score (M) between 3.5 to 5.0 indicates that all six of learning strategies are the most frequently used by the participants)

b. Medium used (M between 2.5 to 3.4 indicates that all six of learning strategies are normally used by the participants)

c. Low used (M smaller than 2.4 indicates all six of learning strategies are rarely used by the participants.

\section{FINDINGS AND DISCUSSION}

The result according learning strategy used by both type of students can be seen from Tables 1 .

Table 1. LLS Used by Successful and Unsuccessful Tenth Grade of Senior High School Students.

\begin{tabular}{llllll}
\hline $\begin{array}{l}\text { Rate of } \\
\text { Success }\end{array}$ & $\begin{array}{l}\text { Number of } \\
\text { participants }\end{array}$ & Min & Max & M & SD \\
\hline Successful & 20 & 2,18 & 4,96 & 3,57 & 0,86 \\
Unsuccessful & 20 & 1,46 & 3,90 & 2,68 & 0,75 \\
All Students & 40 & 1,82 & 4,36 & 3,09 & 0,81 \\
\hline
\end{tabular}

From Table above, it can be concluded that all successful and unsuccessful tenth grade senior high school students were medium users of Oxford's six learning strategies, with the more detail statements are reported in the remaining Tables below.

Table 2. LLS Based on Oxford's category

Used by Successful Students

\begin{tabular}{llll}
\hline $\begin{array}{l}\text { Strategy } \\
\text { Category }\end{array}$ & M & SD & $\begin{array}{l}\text { Ra } \\
\text { nk }\end{array}$ \\
\hline & & & \\
& & & \\
Metacognitive & 4,04 (high use) & 0,79 & 1 \\
Compensation & 3,87 (high use) & 0,82 & 2 \\
Social & 3,76 (high use) & 0,79 & 3 \\
Cognitive & 3,70 (high use) & 0,83 & 4 \\
Memory & 3,17 (medium use) & 0,98 & 5 \\
Affective & 3,01 (medium use) & 1,19 & 6 \\
\hline
\end{tabular}

In the Table 2 shows that each learning strategy has $M$ that represents how frequently they were used by the students. Metacognitive strategy, that 
was placed in rank 1 , with $\mathrm{M}$ of 4,04 was reported as the most frequently used learning strategies by all participants, and followed by compensation strategy (M 3,87), cognitive strategy (M 3,70), social strategy (M 3,76), memory strategy (M $3,17)$, and the last was affective strategy (M 3,01). The result shows that metacognitive, compensation, cognitive, and social strategy were used by successful students in scale of high use. Meanwhile, the strategies including memory and affective strategy were used by successful students in scale of medium use. Although the frequency is not the same for each strategy, the result shows that all strategies were employed by the successful students, it can be concluded that all successful students employed all six strategies in learning English, even though the scale for each strategy was different. Moreover, Table 4.3 below shows the average use of learning strategy performed by unsuccessful students.

On the other hand, as we can see from Table 3, cognitive strategy (M 2,62) was reported as the most frequently learning strategies used by all participants of the unsuccessful, followed by compensation strategy $(\mathrm{M}$ $2,60)$, metacognitive strategy (M 2,54), social strategy ( $\mathrm{M}$ 2,52), memory strategy (M 2,50), and the last was affective strategy (M 2,34). The result also shows that memory, cognitive, compensation, metacognitive, and social strategies were used by unsuccessful students in scale of medium use, which this can be concluded that unsuccessful students were commonly used this strategy even though it was not always used. Meanwhile, the affective strategy was reported as strategy that was rarely used by the students.

Table 3. LLS Based on Oxford's category Used by Unsuccessful Students

\begin{tabular}{llll}
\hline $\begin{array}{l}\text { Strategy } \\
\text { Category }\end{array}$ & Mean & SD & $\begin{array}{l}\text { Ra } \\
\text { nk }\end{array}$ \\
\hline & & & \\
& & & \\
Cognitive & 2,62 (medium use) & 0,84 & 1 \\
Compensation & 2,60 (medium use) & 0,81 & 2 \\
Metacognitive & 2,54 (medium use) & 0,82 & 3 \\
Social & 2,52 (medium use) & 0,67 & 4 \\
Memory & 2,50 (medium use) & 0,76 & 5 \\
Affective & 2,34 (low use) & 0,65 & 6 \\
\hline
\end{tabular}

\section{Discussion}

As it was found from the result of the questionnaire, the successful students tend to use metacognitive strategy among the other strategies. These strategies cover the activity of planning, arranging, managing, and evaluating. This finding was in line with the other previous studies (Ketabi \& Mohammadi, 2012; Simsek \& Balaban, 2008; Lee and Heinz, 2016; 
Sheorey, 1999; Liu, 2004; Lee and Heinz, 2016). On the other hand, cognitive strategy which covers the activities of practicing in repeating, rehearsing, and imitating the language was the most frequent strategy used by unsuccessful students. In relation with previous study, it also found that regular university students are more favorable in using cognitive strategy (Khoshima, 2015; Bobanovic \& Ambrosi, 2006). However, it seems that the present study produced more contrary since the subject in this study was unsuccessful senior high school students, even though a few research found that senior high school students reported using cognitive (Alfian, 2016). Basically, there must be a difference in strategy used because regular university students are higher in level than unsuccessful senior high school students. This is possibly because the participants used in this study was chosen purposively as students in SMAN 2 Jember, in which the school is placed as the top two of the most high reputable in Jember Regency. This might become the reason why, as there are many factors that influence the use of certain learning strategy besides their language competence achievement, they were still medium users of cognitive strategy.

Furthermore, another difference found between the strategy used by successful and unsuccessful students.
From the results, metacognitive, which became the most highly used strategy by successful students, was instead moderately applied by unsuccessful students. This makes the assumption that successful students have the ability to plan clear goals, control, review, and evaluate their learning rather than unsuccessful students who focus more on the way they think, memorize, summarize, and repeat the learning. Even though some strategies might seem more effective than the others (indicating that successful students like to use metacognitive strategies and unsuccessful students refer to use cognitive strategies), in fact, there is no exact theories claim that certain strategies are superior, because there are a lot of researches out there that reported different results of strategies used by students. However, every strategy stands to its own capability in managing the learning. One of the factors that makes them difference is the learners mental thinking themselves. This assumption is derived from the theory of Oxford (1994) who emphasized that, it is important to examine the learner themselves as a whole person, not simply focusing on intellectual aspects of strategies. It means that if learners can choose which strategies are appropriate for them, then it will be very helpful for their learning. 
There are certain characteristics of learners can be found from the result. Successful learners employed all six categorizes of strategies in a highly frequencies rather than unsuccessful learners, which indicated that successful learners were more aware of strategies needs for themselves rather than unsuccessful learners. This is in line with the statement of Chamot and Kupper (1989) who found in their finding that successful students used learning strategies more often, more appropriately, with greater variety, and in ways that helped them complete the task successfully rather than unsuccessful students. Moreover, Simsek \& Balaban, (2010) also stated that successful students used overall strategies significantly more frequently than the unsuccessful students. Nyikos (1987), also defined characteristics as unsuccessful students that often involve non communicative behavior such as translation with heavy use of dictionaries, rote memorization, folding papers into columns to create vocabulary self-tests, and uncreative forms of repetition. This echoes the writer's findings that show unsuccessful learners tend to use cognitive strategies which focus on repeating, rehearsing, and imitating the language.

Even though there might have not enough prove in writers' findings, still, it can be considered as factors that become the weakness of unsuccessful students in learning. The findings of this study provide a guide for English teachers and learners, especially for teaching and learning process. Oxford (1898) stated that appropriate learning strategies help explain the performance of good language learners. It is important for teachers to manage appropriate strategies for students. As what Lee and Heinz (2016) stated in their study, teachers should be aware of strategies that are applied by students by giving the strategy instruction that focus on how to utilize the six strategies as well. It will cause the problem if students use strategies inappropriately, because Vann and Abraham (1990) reported in their study that unsuccessful language learners emerged as active users but they often applied strategies inappropriately. As such, teachers may manage classroom activities and encourage students to apply appropriate strategy.

\section{CONCLUSION AND SUGGESTIONS}

It can be concluded from the study that language learning strategy is one of the important factors that determine whether the students can be an effective learners and help them to become an ultimate success in language learning. To enhancing students' language learning strategy, it required to practice 
more about how to use the learning strategy itself. However, due to the limited of time the writer had, this study only focused their participants' factor in stage of learning, which was senior high school, so this might not enough to add attention in the domain of language learning strategy. Moreover, the instrument in this study was only questionnaire, in which it happened when distributing the questionnaires, the writer found weakness that students might not remember the strategies they had used in the past or might claim to use strategies that in fact they did not use. For future researchers, this study may guide other researcher reviews further, critical, and comprehensive studies which are related to these investigations in order to reveal many aspects in enhancing teaching and learning quality. However, this present study only revealed students' LLS depended on their factors like stage of learning and rate of success, so this might not enough to put the attention in the domain of language learning strategy. There are still lots of factors influence the strategy choice of students like gender, motivation, attitude, learning style; career orientation or field of specialization, national origin, aptitude; language teaching methods, task requirements, and, if relevant, type of strategy training. Perhaps in the future research other writers can conduct the observation towards language learning strategies and select their participants' factors like that has been mentioned before. Moreover, as Chamot (2004) said that there are many kinds of methods to observe students' language learning strategies, such as through retrospective interviews, stimulated recall interviews, questionnaires, written diaries and journals, and think-aloud protocols concurrent with a learning task. Each of these methods has limitations, but each provides important insights into unobservable learning strategies. Perhaps in the future research, the writers can reduce this weakness by conducting research not only by giving questionnaire but also adding more various observations so the data will be more specific.

\section{REFERENCES}

Alfian. 2016. The Application of Language Learning Strategies of High School Students In Indonesia. Indonesian Journal of English Education 3 (2), 140157.

Bobanovic \& Ambrosi. (2006). Language Learning Strategies in Different English as a Foreign Language Education Levels. Retrieved from: https://hrcak.srce.hr/file/35827.

Bruen, J. (2017). Language Learning Strategies for Reading Comprehension: Assessing the 
Strategy Use of Young Adults at Beginners' Level Taking Chinese, German, Japanese or Spanish as Foreign Languages at University. The Language Learning Journal 1(1), 1-17. DOI: 10.1080/09571736.2017.1370606

Buainaian. (2010). Language Learning Strategies Employed by English Majors at Qatar University: Questions and Queries. Asiatic Journal 4(2), 92-120.

Chamot, A. U. (1989). Learning Strategies in Foreign Language Instruction. Foreign Language Annals 22(1), 1322.

DOI: https://doi.org/10.1111/j.19449720.1989.tb03138.x

Chamot, A. U. (1998). Teaching Learning Strategies to Language Students. (ERIC Document Reproduction Services No. ED 433 719).

Chamot, A. U. (2004). Issues in Language Learning Strategy Research and Teaching. Electronic Journal of Foreign Language Teaching 1(1), 14-26.

Chen, H.I., \& Pan, H. (2015). Learner Autonomy and the Use of Language Learning Strategies in a Taiwanese Junior High School. Journal of Studies in Education 5(1), 52-64. DOI:10.5296/jse.v5i1.6972.

Chen, M. (2014). Age Differences in The Use of Language Learning Strategies. English Language Teaching 7(1), 144151. DOI: $10.5539 /$ elt.v7n2p144.

Cohen, A. D. (1998). Strategies in Learning and Using a Second Language. London and New York: Longman.

Dmintreko, V. (2016). Language Learning Strategies of Multilingual Adults Learning Additional Languages. International Journal of Multilingualism
14(1), 6-22. DOI: https://doi.org/10.1080/14790718.20 17.1258978 .

Gerami, H. \& Baighlou, S. (2011). Language Learning Strategy Used by Successful and Unsuccessful Iranian EFL Students. Social and Behavioral Sciences 29, 1567-1576. DOI: 10.1016/j.sbspro.2011.11.399.

Jumai. (2018, Jun 30). Sekolah Favorit Diburu di Injury Time. RadarJember. Retrieved from https:/ / radarjember.jawapos.com/2 018/06/30/sekolah-favorit-diburudi-injury-time/.

Karababaa, Z.C., Ekerb, D.N., Arcak, R.S. (2010). Descriptive Study of Learner's Level of Autonomy: Voices from the Turkish Language Classes. Social and Behavioral Science 9, 1692-1698. DOI: 10.1016/j.sbspro.2010.12.386.

Ketabi, S., \& Mohammadi, A.M. (2012). Can learning strategies predict language proficiency? A case in Iranian EFL context. International Journal of Linguistics, 4(4), 407-418.

Khoshsima, H. \& Tiyar, F.R., (2015). Language Learner Strategies for Building EFL Learners' Autonomy. International Journal of English Language and Translation Studies 3(4), 60-73. Retrieved from http:/ / www.eltsjournal.org

Lee, J., \& Heinz, M. (2016). English Language Learning Strategies Reported By Advanced Language Learners. Journal of International Education Research 12 (2), 67-76. 
Li, Y. (2009). L2 Learners' Attitude to English Vocabulary Learning Strategies. English Didactics. Retrieved from http:/ / www.diva_portal.org?smash /get/diva2:225018/FULLTEXT01.pd f.

Nyikos, M.(1990). Sex-Related Differences in Adult Language Learning: Socialization and Memory Factors. Modern Language Journal 74(3), 273287.

O'Malley, J. \& Chamot, A. (1993). Learning Strategies in Second Language Acquisition. The Modern Language Journal 76 (2), 312-334. DOI: $10.2307 / 329782$.

Oxford, R. L. (1990). Language learning strategies: What every teacher should know. Boston: Heinle \& Heinle Publishers.

Oxford, R. L. \& Nyikos, M. (1989). Variables Affecting Choice of Language Learning Strategies by University Students. The Modern Language Journal, 73 (3), 291- 300.

Oxford, R.L. (1996). Language Learning Strategy around the World: Cross Cultural Perspective. Manoa, HI: Second Language Teaching and Curriculum Center, University of Hawai.
Pannak \& Chiramanee. (2011). Language Learning Strategies Used by First Year Students at Thaksin University, Songkhla Campus, Thailand. Factors Affecting English Language Teaching and Learning 3(1), 1-12.

Qingquan, N., Chatupote, M., Teo, A. (2008). A Deep Look into Learning Strategy Use by Successful and Unsuccessful Students in the Chinese EFL Learning Context. RELC Journal (39), 338-357. DOI: $10.1177 / 0033688208096845$.

Simsek, A. \& Balaban, J. (2010). Learning Strategies of Successful and Unsuccessful University Students. Contemporary Educational Technology, 1(1), 36-45.

Vann, R.J., \& Abraham, R.G., (1990). Strategies of Unsuccessful Language Learners. TESOL, Quartely, 25(2), 177193. 